\title{
METHODOLOGY OF INVESTMENT SYSTEM RESEARCH IN THE ASPECT OF UNPRODUCTIVE CAPITAL OUTFLOW: EXAMPLE OF UKRAINE AND INTERNATIONAL DIMENSION
}

\author{
Oleksandr Laiko', Borys Burkynskyi²
}

\begin{abstract}
The relevance of the topic of development of theoretical and methodological approaches to investment system regulation under influence of unproductive capital outflow is justified by significance of financial capital movements from groups of countries to others, caused by inappropriate institutional support for strategic investments. Aim of the proposed research is the development of methodological approaches to study and regulation of investment system development that allow to provide analysis of actual modern tendencies of investment system development, to estimate the influence of capital outflow on financial provision of investment process and to design regulating framework for shortening of unproductive financial capital outflow. The work is dedicated to research of theoretical, methodological and applicable basis of investment system development regulation in aspect of reducing of unproductive financial capital outflow with calculation of possible effect from involvement of reduced volumes of capital outflow into investment process. The research methodology, which is based on sustainable development and principle of balance of the stakeholders' interests, includes approaches of system, theoretical and empirical analysis that allows us to identify the sense and structure of investment system in a sample of Ukraine and other 11 countries. Due to the statistical and econometric methods the estimation of the dynamics and regularities of capital investments are explored and the role of financial capital outflow in economic development of the country is estimated as percentage of GDP and as potential implicit resource that can be involved in investment process. The authors propose the methodology of investment system research and regulating from positions of institutional support embittering for renewal of invested capital and for attraction of new strategic investors. The provided systematization of theoretical positions in the sphere of investments and capital migration allows to obtain the definition of sense of investment system, to discover the regularities of its development and to identify the phenomenon of unproductive outflow of financial capital. It is found that the main criteria of unproductivity of capital outflow is excess of losses and expenses for national economy, caused by such migration of resources, under possible benefits. Conclusion. The hypothesis of existence of direct positive dependence of unproductive outflow of financial capital from growth of the national economic is proved in a sample of Ukraine due to the use of empirical statistical study method. It is identified that the key factor that provokes capital outflow is inappropriate institutional support for strategic investments. The proposed model of estimation of correlation between capital investments and value added allows to calculate the possible economic, social, and budgetary effect from involving into economy of Ukraine investments saved from outflow, that can result in more than 22.6 bln USD of value added growth.
\end{abstract}

Key words: investment system, capital outflow, illicit financial flows, reinvestments, reproduction of capital.

JEL Classification: E22, F21, F38

\footnotetext{
Corresponding author:

${ }^{1}$ Institute of Market Problems and Economic\&Ecological Research

of the National Academy of Sciences of Ukraine, Ukraine.

E-mail: alexlayko@gmail.com

ORCID: https://orcid.org/0000-0001-7082-0862

ResearcherID: D-8293-2018

${ }^{2}$ Institute of Market Problems and Economic\&Ecological Research

of the National Academy of Sciences of Ukraine, Ukraine.

E-mail: burkinskij@nas.gov.ua

ORCID: https://orcid.org/0000-0001-9303-0898

ResearcherID: U-9714-2017
} 


\section{Introduction}

The relevance of the proposed research, which is dedicated to development of actual methodological approaches to the regulation of investment system transformation, is justified by the importance of investments for economic development of Ukraine and other countries due to the powerful influence of invested capital on the structure of economic systems in sectoral, spatial and other dimensions. The modern tendencies of investment system transformation in direction of predominance of reinvestments in the total structure of investments make the question of effective turnover of invested resources relevant in the aspect of the provision of appropriate conditions for reinvestments of financial resources without abnormal withdrawals of capital and unproductive outflow abroad. The phenomenon of capital outflow that takes place in the Ukrainian economy and economies of other countries is characterized by the significant volumes, which in some cases are equivalent to the total capital investments. The fact that capital outflow as powerful factor influencing on transformation of investment system is poorly studied justifies the urgency of the proposed research and allows us to formulate the main issues of the study. The aim of the research is to develop theoretical and methodological approaches to investment system regulation in aspect of reduction of unproductive capital outflow based on means of creation of appropriate conditions for strategic investments involvement in national economy and improving the regulatory framework in investment sphere that is conceptually based on realization of economic, social, governmental and other interests of stakeholders. The tasks of the research include: formulation of the actual methodology of investment system development research based on principles of renewal of invested resources, prevention of ineffective capital outflow, diversification of sources, sustainability of investment processes, balance of stakeholders interests and others; improvement of terminological basis in the sphere of financial capital outflow; design of the scope of methodical approaches to estimation of efficiency of investment system functioning in national and international dimensions, the evaluation method of volumes of unproductive capital outflow, method of the analysis of the significance of capital outflow influence on economic system; detection of strategic directions for the regulation of investment system development; methodic approach to the calculation of the possible sustainable effect of proposed regulation means implementation, that is based on the use of an econometric model.

The novelty of the results obtained in the research consists of classification of types of financial capital movement according to the degree of legality; scope of principles of investment system development, designed according to directions of modern institutional framework in Ukraine and the EU countries, in aspect of capital outflow reduction; methodology of investment system transformation regulation, which unlike others, is based on balance of economic, social, and budgetary interests of the stakeholders; mechanisms of regulation of investment system on national level that include institutional, financial, credit, economic, administrative means; methodic approach to calculation of complex effect from the involving into the national investment process of volumes of capital outflow saved from unproductive withdrawal. The research findings are characterized by theoretical and applied value because they can be used not only in scientific sphere but also in sector of governance of economic development.

Possible restrictions of the research include lack of constant sources of data concerning some types of capital outflow, namely data of volumes of financial resources transferred abroad as payments for reinsurance operations are not always available on official sites of Ukrainian authorities and statistical agencies but it is not critical option for the research because of its relatively small share in total capital outflow.

\section{Overview of the relevant publications}

Scientific works by Scott Davis and Eric van Wincoop (2018) are dedicated to the research of the correlation between capital inflows and outflows in a sample of 127 advanced and developing countries. The authors justified that in the most countries there is strong, increasing correlation between capital inflows and outflows but the character of this link is changeable. The results obtained by the authors due to the modelling of correlation between capital flows and financial globalization discovers the tendency of decrease of volumes of financial capital inflows caused by factor of financial globalization. But authors have not described the character and the main factors of the influence of capital inflows on capital outflows. The solution of this problem may be set as one of the tasks of our research because we put forward the hypothesis of direct positive dependence of capital outflow volumes from the level of economic growth and activity in the country that may be expressed with the help of indicators of GDP, gross value added or financial capital inflow.

Heiets (2016) argues that the economy of Ukraine and the economic systems of the most developing countries are characterized by contradictory trends of investments dynamics caused by influence of different internal and external factors, the impact of which is able by reason of institutional insolvency of national transitional economy that also causes the illicit financial flows of capital but direct correlation between institutional state of investment sphere in the national economy and dynamics of illicit financial flows is not researched by the author.

Paskhaver (2007) conducted a detailed analysis of the genesis, essence, structure and causes of capital 
formation in Ukraine, calling his research: “...study of the anatomy of Ukrainian capital" (Paskhaver, 2007 , p. 23). The author puts forward and proves the hypothesis of imperfection and immaturity of institutional support to attracting of long-term strategic investments in Ukraine. Continuing the author's opinion, in this study we try to confirm the hypothesis that the absence of institutional investors support makes large amounts of financial capital earned in the national economy to be exported to the economic systems of other countries with reliable conditions for storage or investments.

Lunina, Bilousova, \& Frolova (2020) analyze investment drivers as means of stimulation of economic system development and explore the role of tax reforms in creation of attractive investment climate that can prevent financial resources outflow.

Ilyina (2017) proposes methodology of investment climate evaluation as an effective research method of business climate of the national economic system that can describe the level of activity of foreign and internal investors and highlight possible negative impacts on country's development.

Holz (2020) considers investment statistics as source of estimation of productivity level of national economic system, on example of Chinese economy. The author examines the key definitions in investment sphere, considers an aspect of data availability, and technical issues of the investment data of the People's Republic of China (PRC). He also explores relationship between fixed asset investment and gross fixed capital formation, tries to highlight the problem of investments data falsification in PRC and the author indirectly approaches to research of the question of illicit flows of capital.

The methods for research of investment sphere in economy of Ukraine proposed by Vartsaba and Leshuk (2017) are based on development of evaluation indicators for providing of the estimation of investment attractiveness of regions in Ukraine.

Kazuo Ueda (1990) has provided thorough theoretical and empirical research of Japanese capital outflows for the period of the 1980s and tried to discover the driving forces of this phenomena and its role in the economic development of the country.

Dhar (2021) has provided research that is dedicated to identification of extreme capital flows in emerging markets in a sample of 36 economies.

The analyzed scientific works of various authors, which are devoted to the study of capital outflows, are thorough, comprehensive with a powerful scientific apparatus, but they do not take into account issues of a theoretical nature, namely: lack of terminological constancy in sphere of capital outflow research; formulation of a modern methodology for studying of the investment system on basis of invested capital renewal, in the context of the implementation of the model of sustainable development and in the aspect of influence of unproductive capital outflow. A key applied issue is represented by the development of organizational and economic mechanism for regulating of the investment system at the national level in terms of improving its social efficiency, ensuring returns for all stakeholder groups, increasing institutional strength and creating favorable conditions for investments reproduction and for the reducing of unproductive capital outflow abroad.

\section{Research methods}

The research is aimed at the design of the methodology of investment system study and regulation in context of modern conditions of domination of reinvestment operations in total structure of the investments and under influence of unproductive capital outflow. The following methods are used in the research: method of system analysis and synthesis (determining the sense and structure of investment system, identifying the dominant driving force of the modern investment process, design of classification of types of capital outflow); theoretical and empirical analysis (formation of scope of principles that are actual for modern investment system development, estimation of the role of capital outflow in the investment process); method of institutional analysis (study of regulatory documents, international and national policies in investment sphere); method of comparison and scientific abstraction (estimation of significance of capital outflow for economic systems of different countries), statistical and logical analysis methods (dynamic series and structure analysis of investments and capital flows, averages, shares, per capita indices, grouping of investments according to financial sources, comparisons of total and per capita investments, capital outflow data in different countries), graphical methods (schemes and diagrams of investments and unproductive capital trends), method of modelling (estimation of the dependence of gross value added from capital investments for the purpose of calculation of sustainable effect from involving into the investment process of capital that is saved from unproductive withdrawal abroad), methods of regulation means and policy design (formation of strategic directions for the regulation of investment system development, design of economic and organizational mechanisms for improvement of institutional framework in investment sphere with the aim of strategic investments stimulating).

The methodical toolkit of the research is used for verification of the main scientific hypothesis that is formulated as follows: the investment system development of any modern country is highly dependent on reinvestment operations and sustainable effective functioning of the investment system is possible with the help of appropriate institutional support that facilitates 
strategic investments, otherwise the growth of business activity in the national economy, expressed by GDP indicator increase, leads to progressing unproductive capital outflow.

\section{Results of the research}

Despite numerous studies of outstanding scientists in the field of investment activity in Ukraine and in the regions (Heiets, 2006), unresolved issues remain the implementation of priorities for the development of the investment system with proper impact on the national economy in the form of organizing hightech competitive industries, maximizing the created added value based on deep processing of domestic raw materials, which will contribute to effective economic transformation in the context of integration into EU markets and participation in the international division of labor. The key category that characterizes all the features and components of the investment process in the country is the investment system, which is represented by a combined set of all elements and components of the investment process to convert resources into capital and produce reproduction cycles.

The results of the conducted research (Burkynskyi, Laiko \& Talpa, 2018) show that in the national economy and on a global scale, investment has acquired the signs of consistency, expanded its classical boundaries, including such stages as attracting, investing resources, reproduction and reinvestment or withdrawal from circulation, and has become an integral part of social production.

For the modern economic system, the processes of reproduction of invested capital as a source of renewal of investment resources are important, as since the global financial crisis, the importance of reinvestment processes in most countries of the world has increased significantly, and the use of own funds of enterprises and business entities as a source for investment has become a key feature of the investment process (Figure 1). The tendencies of reinvestments domination and the importance of stable conditions for renewal of invested resources are also highlighted in agenda and conclusions of the sixth World Investment Forum (2018).

The investment process in Ukraine for the entire period of independence is characterized by the use mainly of own funds of enterprises and organizations as the main source of capital investment (from $50 \%$ to almost 70\%).

Therefore, the investment process and components of the investment system should be studied in the context of the stages of attracting resources and making capital investments, reproducing capital and using the resulting effect (reinvesting or extracting growth on invested capital), while assessing the ability of the country's economy to contribute to the reproduction and increase of capital attracted to economic turnover, since this ability automatically becomes an indicator of the overall ability to attract investment resources.

The formation of the methodology and priorities for research and regulating the development of the investment system of Ukraine (Figure 2) is determined in accordance with the current features of the functioning of the national economy and challenges, that are discovered in previous researches (Burkynskyi, Laiko \& Talpa, 2018), and require immediate solutions, namely:
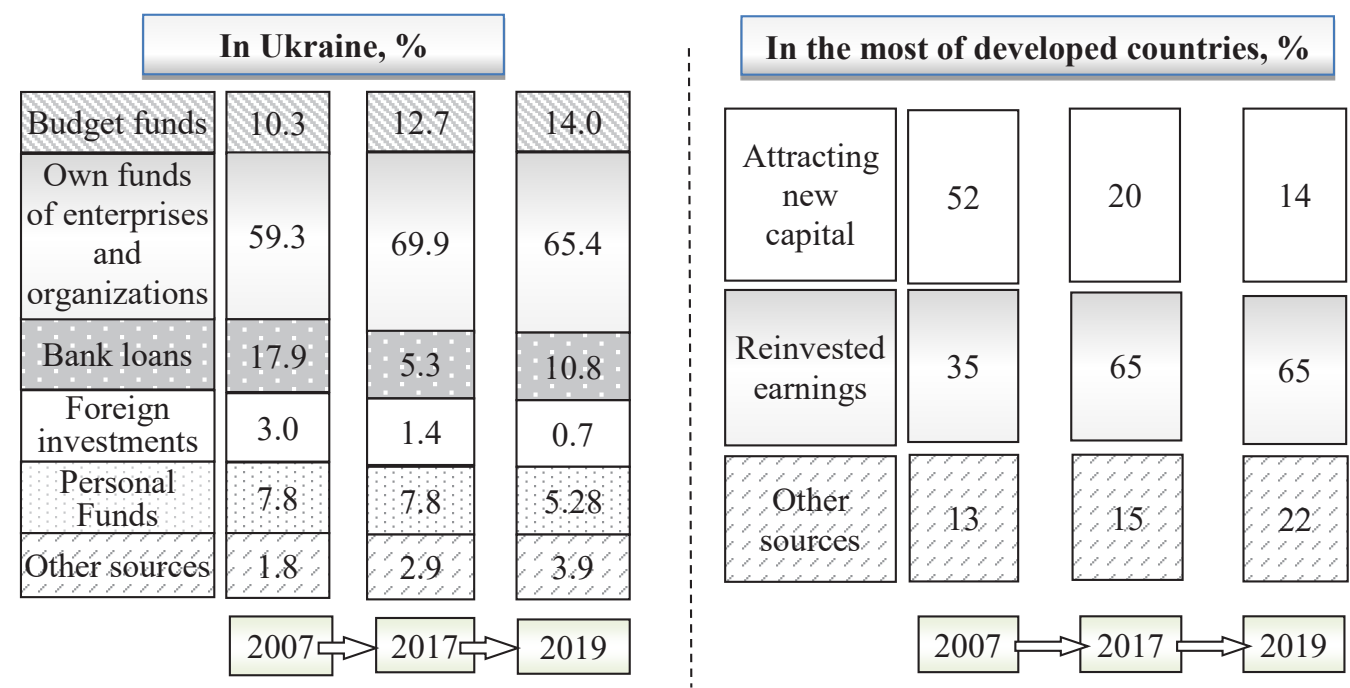

Figure 1. Dynamics of the structure of sources of financial support of the investment process in Ukraine and in the most of the developed countries of the world

Source: concluded according to the official data of the State Statistics Service of Ukraine (2019) and UNCTAD Global investment trends monitor (2019) 


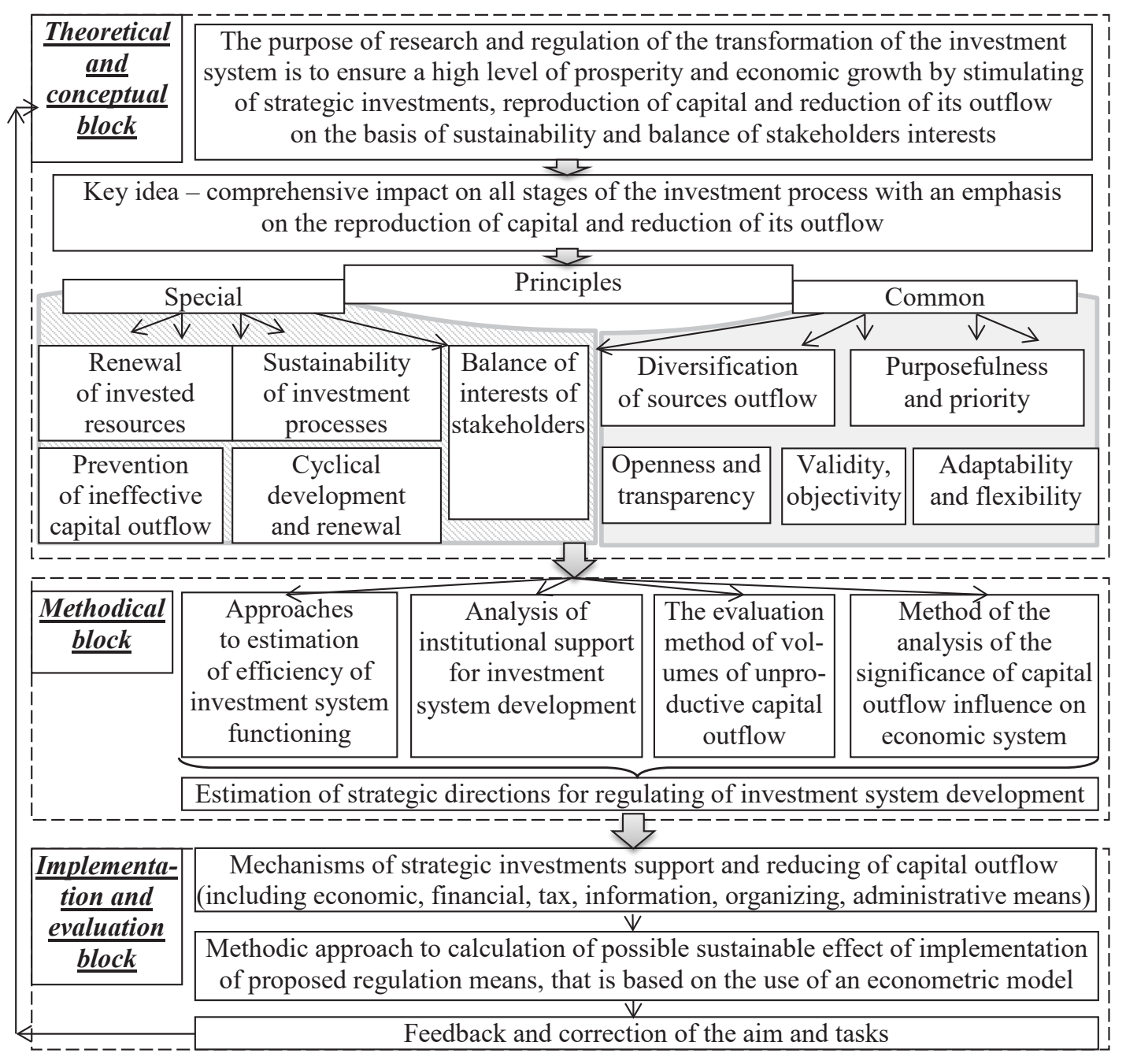

Figure 2. Methodology of research and regulation of investment system development in aspect of unproductive capital outflow reduction

1) Hidden decrease in overall investment activity in the national economy, expressed by an increase in the quantitative indicators of the investment process achieved due to the impact of inflation, and a drop in real investment volumes in terms of USD equivalent or purchasing power parity;

2) Absence of a positive modifying effect of investment, which leads to a raw material type of development of the national economy, deep deindustrialization is developing; 3) Consistency of investment quality characteristics without significant changes;

4) Progressive outflow of financial capital abroad and the dominance of incomplete investment process cycles, lack of strategic foreign investment;

5) Non-compliance of institutional support with the real needs of investment system development;

6) Lack of institutional support for strategic investment at the project level;

7) Lack of levers of influence on improving the level of well-being in territorial economic subsystems (at regional and basic levels);
8) Need for compliance and consistency with the provisions of international investment policy and domestic strategic documents in order to participate more effectively in international economic exchange.

According to the results of the analysis of the dynamics and structure of the investment process in Ukraine in recent years, a number of negative processes become identified as hidden, but with impact on the state of the national economic system.

These processes include:

1) A positive change in the volume of capital investment, which is clearly linked to inflationary processes and the growth of consumer prices, but differs from real tendencies of capital investments decrease in constant prices in USD can be seen on Figure 3.

Thus, the growth of capital investment in Ukraine in current prices occurred from 2006 to 2019 from 149 billion UAH up to 624 billion UAH at the same time, the inflation with an average annual index value of $112.1 \%$ and an accumulated value of $416.6 \%$ for 2006-2019 led to an incorrect determination of the 


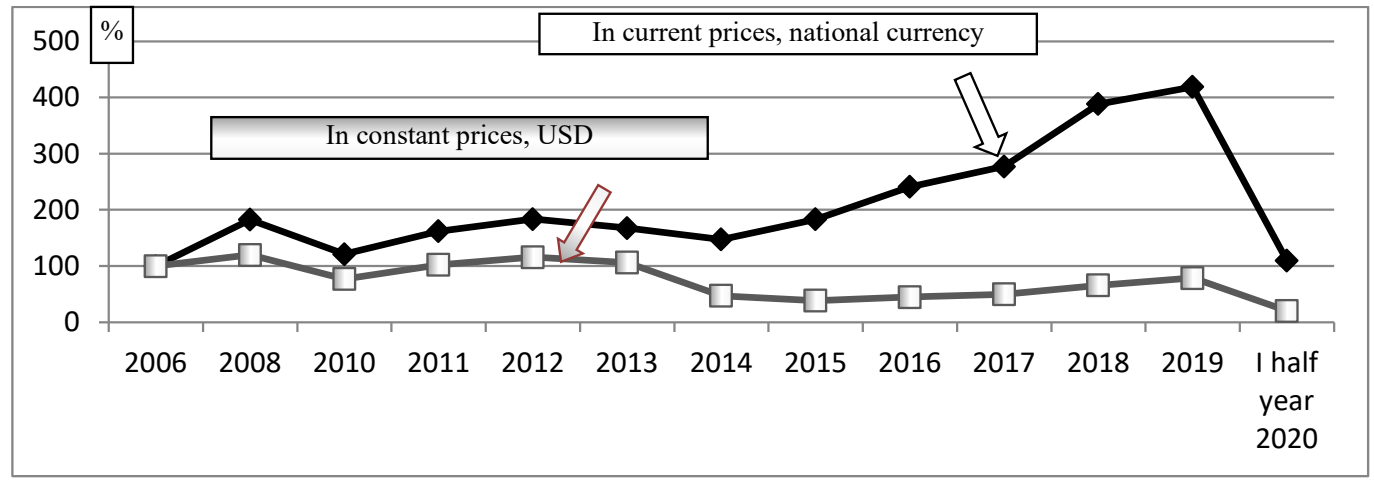

Figure 3. Indices of capital investments in economy of Ukraine

Source: concluded according to the official data of the State Statistics Service of Ukraine (2019), The National Bank of Ukraine (2019)

real amount of capital investment and a hidden drop in investment activity (Table 1).

The decline in investment volumes in terms of USD equivalent occurred from 29.5 bln USD (in 2006) to 23.2 bln USD (in 2019). That is, there has been no real increase in the volume of capital investment in the Ukrainian economy during the study period, but an imaginary increase in current prices has taken place due to the fact that the increase in the inflation index and the fall in the national currency exchange rate against USD occurred at a faster pace than the decrease in the volume of capital investment in fixed prices and in a stable currency equivalent.

The introduction of the values of the capital investment indicator for the first half of 2020 into the calculations made it possible to demonstrate a general trend towards a drop in investment activity due to the COVID-19 pandemic. Despite the fact that the value of the capital investment indicator in 2020 is taken for a six-month period, its value in both current and fixed prices, according to official statistics (the State Statistics Service of Ukraine, 2020), is $65.1 \%$ compared to the corresponding period of the previous year (i.e., the first half of 2019).
2) The constancy of the structure of sources of financial support for capital investment in Ukraine and their non-diversification with a constant dominance of own funds of enterprises and organizations. Minor changes in the structure of sources of financing for capital investments in Ukraine occurred due to the decentralization reform and the redistribution of budget powers, which allowed territorial communities to invest a large amount of financial resources in their own development, that resulted in the increase of investment, financed by local budgets from 5.7 billion UAH up to 56.5 billion UAH, according to the data of the State Statistics Service of Ukraine (2020).

3) The absence of significant changes in the structure of capital investment by type of economic activity, where the stable leader is industrial production, mainly extractive industry, and agriculture (The State Statistics Service of Ukraine, 2020). However, the amount of capital investment in these activities is not characterized by the rapid growth necessary for the renewal of production capacity, and the existing, even, drop in investment volumes in dollar terms, despite the fact that most of the production equipment today is purchased by import and, in fact, represents compensation for

Table 1

Dynamics of capital investment in the Ukrainian economy:

the impact of inflationary phenomena and changes in the exchange rate

\begin{tabular}{|l|c|c|c|c|c|c|c|c|c|c|c|}
\hline \multicolumn{1}{|c|}{ Capital investment: } & 2006 & 2008 & 2010 & 2012 & 2014 & 2015 & 2016 & 2017 & 2018 & 2019 & $\begin{array}{c}1 \text { st half } \\
\text { of } 2020\end{array}$ \\
\hline - in current prices, bln UAH & 149 & 272.1 & 180.6 & 273.3 & 219.4 & 273.1 & 359.2 & 412.8 & 578.7 & 624 & 163.8 \\
\hline - in comparable prices, bln USD & 29.5 & 35.3 & 22.7 & 34.2 & 13.9 & 11.4 & 13.2 & 14.7 & 19.4 & 23.2 & 6.0 \\
\hline $\begin{array}{l}\text { Average annual exchange rate, } \\
\text { UAH/ USD }\end{array}$ & 5.05 & 7.7 & 7.96 & 7.99 & 15.77 & 24 & 27.19 & 28.06 & 27.2 & 25.85 & 26.71 \\
\hline $\begin{array}{l}\text { Inflation index, \% (accumulated } \\
\text { value for the period from 2006 } \\
\text { to 2019 is 416.6\%, average } \\
\text { value for the period is 112.16\%) }\end{array}$ & 111.6 & 122.3 & 109.1 & 99.8 & 124.9 & 143.3 & 112.4 & 113.7 & 109.8 & 104.1 & 102 \\
\hline
\end{tabular}

Source: concluded according to the data of the State Statistics Service of Ukraine (2020), the National Bank of Ukraine (2020) 
the added value created abroad, that is, there is an unproductive outflow of financial capital.

4) Low activity of strategic foreign investors. Thus, foreign direct investment annually covers only $1.5 \%-3 \%$ of the country's total investment demand, in 2019 year - only $0.7 \%$, while operations of withdrawal and receipt of previously invested capital are characterized by a large order of magnitude and depend on macroeconomic and political stability. In 2014 and 2015, there was a rapid withdrawal of capital previously invested in Ukraine by other countries in the amount of 13 billion USD, according to our own calculations (Laiko, 2015, p.205) and 4,570.9 million USD according to Global Financial Integrity data (2020). Strategic investment has almost no place at all, since the main suppliers of imported capital are offshore countries, which are also the largest consumers of the national investment resource.

\section{Role of financial capital outflow in development of investment system: international and national aspects}

Characteristic of the national investment system is the phenomenon of unproductive outflow of financial capital, which is significant in its volume but still insufficiently systematically studied (Figure 4).

A significant problem in diagnosing and regulating the process of unproductive outflow of financial capital is the lack of a well-established methodological approach. To date, there is still no normative gradation of definitions that characterize the movement of financial capital and methods for calculating capital outflows.
Guided by the approaches of semantic system analysis, the scientists of the Institute of market problems, and economic and ecological research of NAS of Ukraine proposed a classification of definitions in the field of export of financial capital abroad, and also developed a methodological approach to calculating the volume of unproductive outflow of financial capital from the national economy and from certain regions of Ukraine.

The significance of the negative impact of the phenomenon of unproductive outflow of financial capital is manifested in the deprivation of significant investment resources in the national economy (Table 2).

Given in Table 2 volumes of unproductive export of financial capital determined according to the methodology developed by Institute of market problems and economic-ecological research of the NAS of Ukraine (Laiko, 2014, p. 205). According to Global Financial Integrity methods (2020), with illegal capital withdrawal volumes in the amount of 11,676 billion USD every year, Ukraine was ranked 14th out of 150 countries in the world (the rating was compiled in 2017). The methodological approach to determining the volume of illegal export of financial capital used by Global Financial Integrity (GFI), although informative, is not objective enough due to the different scale of the countries being compared, their area and population. If we calculate the volume of unproductive leakage of financial capital per 1 person (in per capita dimension), then in Ukraine this amount is 259.47 USD per year and it exceeds similar indicators of countries such as China (211.76 USD per 1 inhabitant), India (29.9 USD), but is less than in Mexico (505.7 USD per 1 inhabitant) and

Movement (export) of financial capital

The unproductive outflow of financial capital is the legal export of capital, defined:

- according to the balance of payments (the amount of negative balances on items of current transactions, financial transactions, capital transactions, the negative value of the item "errors and omissions");

- according to the balance of payments and official statistics as the sum of indicators (investments abroad, losses from reinsurance operations, other financial and offshore transactions, the growth of foreign currency presence in national economy (as mean of savings), a negative value of item "errors and omissions";

- use of other legal ways for capital export, such as tax rates differences in reinsurance operations in Ukraine and abroad;

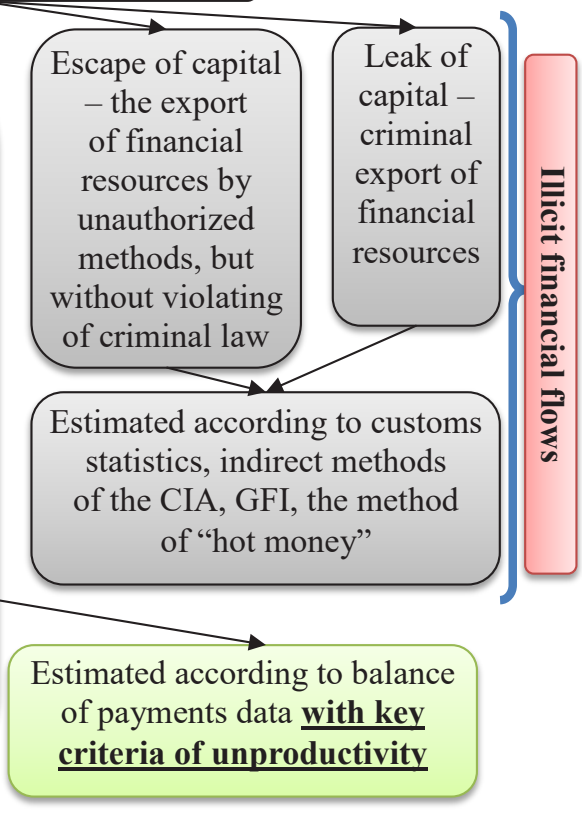

Figure 4. Classification of types of financial capital export and definition of capital outflow 
Table 2

Significance of the amount of financial capital export from the economy of Ukraine, bln USD

\begin{tabular}{|l|c|c|c|c|c|c|c|c|c|c|c|c|c|}
\hline \multicolumn{1}{|c|}{ Indicators } & 2006 & 2008 & 2009 & 2010 & 2012 & 2013 & 2014 & 2015 & 2016 & 2017 & 2018 & 2019 & $\begin{array}{c}1 \text { st half } \\
\text { of 2020 }\end{array}$ \\
\hline Capital outflow* & 2.7 & 2.4 & -2.99 & 8.7 & -1.8 & -3.2 & -0.6 & 6.1 & 11.6 & 11.7 & 12.1 & 12.3 & -0.8 \\
\hline Investments & 29.5 & 35.3 & 29.7 & 22.7 & 34.2 & 31.3 & 13.9 & 11.4 & 13.2 & 14.7 & 21.4 & 23.1 & 6.06 \\
\hline Capital outflow, \% to investments & 9.2 & 6.8 & $\mathrm{x}$ & 38.3 & $\mathrm{x}$ & $\mathrm{x}$ & $\mathrm{x}$ & 53.5 & 87.9 & 79.6 & 56.5 & 53.2 & $\mathrm{x}$ \\
\hline GDP & 112 & 129 & 121 & 135 & 176 & 183 & 101 & 82.9 & 87.7 & 106 & 132 & 141.5 & 32.1 \\
\hline Capital outflow, \% to GDP & 2.4 & 1.9 & $\mathrm{x}$ & 6.4 & $\mathrm{x}$ & $\mathrm{x}$ & $\mathrm{x}$ & 7.4 & 13.2 & 11.0 & 9.2 & 8.7 & $\mathrm{x}$ \\
\hline
\end{tabular}

Source: calculated according to the data of the State Statistics Service of Ukraine (2020) and the National Bank of Ukraine (2020)

in the Russian Federation (297.3 USD per 1 inhabitant). The phenomenon of unproductive outflow of financial capital is quite serious problem for the national economies of 11 other counties, which we have analyzed with the use of GFI methodology (Table 3).

As it is seen from Table 3, the influence of capital outflow (illicit financial flows) on the economic development of different countries is quite significant. The strongest impact is identified on economies of relatively small European countries such as Hungary, Poland, and Romania, which are characterized with transit geographical location, and Mexico where the level of shadow economy is quite high.

It is also worth taking into account the powerful influence of unofficial institutional support in the implementation of the investment process, according to which illegally or semi-legally withdrawn financial resources from abroad can actually be investments aimed at expanding the country's spheres of influence abroad (opening new production facilities or representative offices of national producers in other countries, using local resources of other countries to create national added value, to create an economic basis for the development of settlements of citizens in other countries, etc.). Unfortunately, for Ukraine, such positive aspects from the withdrawal of financial capital are not typical and almost all the facts of the withdrawal of financial resources abroad are manifestations of unproductive withdrawal of capital.

The dynamics of financial capital outflow is closely linked to transformational changes in society, behaving both as a factor of influence on the investment process and as an indicator of economic and political events (Figure 5).

As it is seen from the linear graphics of Figure 5, there is a quite strong correlation between dynamics of unproductive outflow of financial capital and GDP in Ukraine. The visually detected correlation allows us to prove the hypothesis of existence of strong positive dependence of capital outflow volumes from GDP growth caused by the conditions of lack of institutional support of strategic investments.

One of the most significant components of the indicator of unproductive outflow of financial capital in Ukraine is operations of export of raw materials and export of high-tech products, despite the fact that objective prerequisites for the preservation and formation of new production facilities with a high degree of processing and significant added value of final products in Ukraine are available. The conducted studies of prices for export and import of food products in Ukraine (Laiko, 2014, p. 320) allowed us to determine the pattern of excess prices for imports to Ukraine in comparison with exports from 1.6 to 14 times (Table 4), which is a consequence of deindustrialization, trends in the export of raw materials and imports of goods with a high degree of processing and added value.

The presence of an outflow of financial capital in the implementation of foreign trade is also indicated by the negative balance of payments of Ukraine, which in terms of operations with goods has a consistently

Table 3

Significance of the amount of financial capital outflow (illicit financial flows) from the national economies of different countries

\begin{tabular}{|l|c|c|c|c|c|c|c|c|c|c|c|}
\hline & Russia & Belarus & Poland & China & Turkey & India & Mexico & Brazil & Hungary & Romania & Moldova \\
\hline $\begin{array}{l}\text { Capital outflow (illicit } \\
\text { financial flows), bln USD }\end{array}$ & 42.93 & 1.08 & 52 & 296.0 & 24.75 & 40.9 & 64.52 & 20.80 & 21.57 & 10.49 & 0.21 \\
\hline Popula-tion, mln. persons & 144.4 & 9.47 & 37.98 & 1398 & 83.43 & 1366 & 127.58 & 211.1 & 9.77 & 19.36 & 2.66 \\
\hline GDP, bln USD & 1670 & 60.03 & 587 & 13895 & 771.4 & 2713 & 1221 & 1885 & 157.88 & 241.6 & 11.46 \\
\hline Capital outflow, \% to GDP & 2.57 & 1.79 & 8.86 & 2.13 & 3.21 & 1.51 & 5.28 & 1.10 & 13.66 & 4.34 & 1.82 \\
\hline $\begin{array}{l}\text { Capital outflow per capita, } \\
\text { USD/ 1 person }\end{array}$ & 297.3 & 114.04 & 1369.1 & 211.8 & 296.7 & 29.9 & 505.68 & 98.56 & 2207.5 & 541.8 & 78.63 \\
\hline
\end{tabular}

Source: calculated according to the data of the Global Financial Integrity (2020) and the World Bank (2020) 


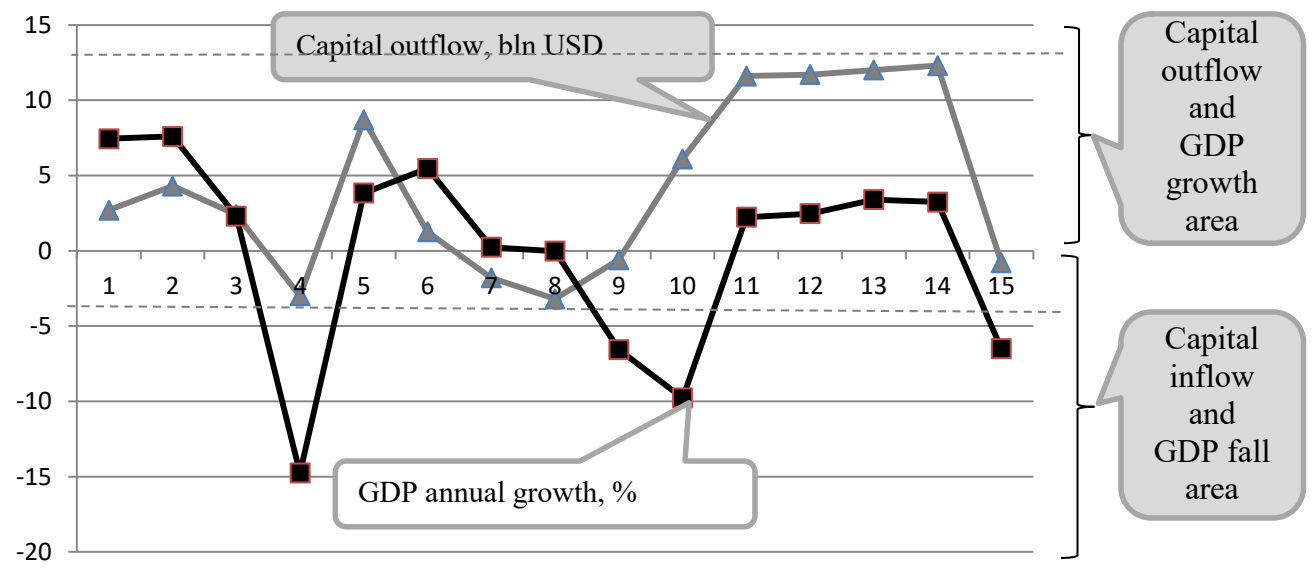

Figure 5. Dynamics of unproductive outflow of financial capital and GDP in Ukraine

Source: calculated according to the author's methodology based on the official data of the World Bank (2020), the State Statistics Service of Ukraine (2020) \& the National Bank of Ukraine (2020)

Table 4

The average price of 1 ton of food exports and imports from Ukraine to countries EU and Eastern Europe in (average value 2006-2019)

\begin{tabular}{|l|c|c|}
\hline \multicolumn{1}{|c|}{ Indicators } & EU-28 & Eastern Europe \\
\hline Total export, th of tones & $6,918.7$ & $3,837.1$ \\
\hline Total export, bln USD & 1.5 & 4.3 \\
\hline Average price of 1 ton of export, USD & 215.5 & 687.7 \\
\hline Total import, th of tones & 821.3 & 1.3 \\
\hline Total import, bln USD & 2.5 & $1,844.1$ \\
\hline Average price of 1 ton of import, USD & $3,066.61$ & 1.6 \\
\hline Prices ratio & 14.2 & \\
\hline
\end{tabular}

Source: calculations are based on the balance of payments data (The National Bank of Ukraine, 2020)

negative value over the past decade from 6 to 22 billion USD (The National Bank of Ukraine, 2020).

\section{Strategic directions of investment system development regulation and modeling of possible effects from unproductive capital outflow reduction}

Transformation processes that occur in the national economy and affect changes in the investment system are caused by improper organization and insufficiently effective institutional support for the investment process. Because of the fact that the main emphasis in regulatory documents of an investment nature in recent years was placed on attracting foreign capital, control over stimulating reproduction processes in strategic economic activities was lost.

The prospects for regulating the development of the investment system in Ukraine determined as a result of the conducted research are mainly in the plane of institutional transformations, since this aspect is one of the most significant and problematic for the national economy. According to actual state of economic development in Ukraine, the following strategic directions aimed to the decrease of unproductive capital outflow are to be proposed in the following forms:

- To improve the regulatory framework in investment sphere;

- To stimulate strategic investments;

- To improve the level of investments protection;

- To increase the proposal for investments into the national economy;

- To foster the capital turnover in economic system;

- To create protective framework for national economy and for investments avoiding breaking of law and international agreements.

The most powerful regulative impact on investment system in aspect of capital outflow reduction may be caused by economic and tax mechanisms. Results of our previous researches (Burkynskyi, Laiko \& Talpa, 2018) show that during the first year of regulation it is possible to prevent the outflow of at least of the $3 \mathrm{rd}$ part of financial capital from the total annual volume. The calculation of the financial performance of the proposed regulatory measures, which is carried out on the basis of an interpretation of the principles of sustainable development, indicates the appropriateness of stimulating reinvestment processes, since this should bring returns in such dimensions: 
- Economic dimension (increase in value added and profit for investors);

- Budget dimension (increase in taxes and fees);

- Social dimension (increase in employee benefits, social benefits, fees).

To calculate the estimated significant effect obtained from reducing unproductive capital outflows and directing such financial flows to support the investment process in the country, it is proposed to develop a model of the dependence of gross value added on capital investment.

Using official statistics on the volume of gross value added and capital investment in Ukraine, we have concluded such a model using a step function as such, which allows us to obtain the greatest approximation to the simulation of the real relationship between gross value added and capital investment, formally justified by the maximum value of the coefficient of determination (Figure 6)

The equation that describes dependence of value added (VA) from capital investments (CI) has the following form:

$$
\mathrm{VA}=11,694^{*} \mathrm{CI} 0,7233
$$

According to the model and to the data of unproductive financial capital outflow we make the following suggestion: the reduction of even the 3rd (2.5 bln USD) part of unproductive outflow of financial capital as of 2018 - 2019 years and reinvestment of this volume in economic turnover allows to obtain an estimated increase of:

- gross value added to 22.69 bln USD (612.6 bln UAH); - tax incomes to budgets of various levels (corporate income tax, personal income tax, value added tax) 5.84 bln USD (157.7 bln UAH);
- social benefits of 5.54 bln USD (149.5 bln UAH), including wages of 4.54 bln USD (122.6 bln UAH), social deductions to the wage fund of 0.998 bln USD (26.95 bln UAH).

Calculations of possible effects from the involving into the investment process of additional financial resources saved from outflow are provided with the following assumptions:

- the main taxes that are to be obtained include corporate income tax (18\% of net profit), personal income tax ( $18 \%$ of wages), value added tax $(20 \%)$;

- share of wages in gross value added is $20 \%$, share of profit in gross value added is $12 \%$ (according to the data of our calculations of average rate of salaries and profit in gross value added);

- the rate of social deductions (the signal social fee in Ukraine is 22\%).

Possible growth of gross value added due to the use of proposed means of investment system regulation and capital outflow reduction is 22.69 bln USD or $20.4 \%$ of present value of this indicator as of 2019 .

\section{Conclusions}

The methodology of investment system development regulation that is designed in the research include improved terminological basis, actual conceptual approach that meets modern requirements of international and national investment policies, blocks of common and special principles, namely: principles of renewal of invested resources, prevention of ineffective capital outflow, diversification of sources, sustainability ofinvestment processes, balance of stakeholders interests and others; scope of methodological approaches to estimation and regulation of efficiency of investment

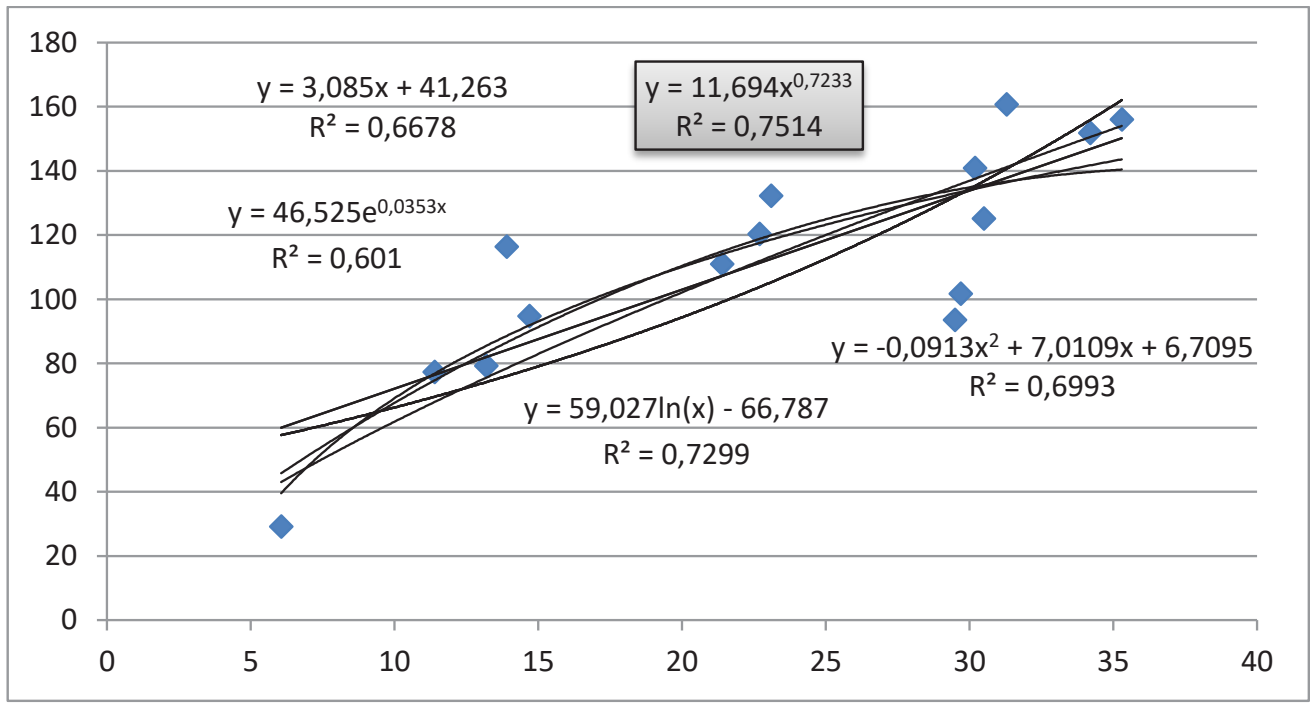

Figure 6. Dependence graphs of value added from capital investments in Ukraine, identified for the period 2006-2019

Source: calculated according to the data of the State Statistics Service of Ukraine (2020) and the World Bank (2020) 
system functioning in aspect of unproductive capital outflow reduction.

One of the main theoretical goals obtained in the research - is the identification of actual definitions of investment system and of unproductive capital outflow with impact on renewal processes importance for institutional support of strategic investments. The phenomenon of unproductive capital outflow is identified in total system of classification of types of financial capital movement as completely legal way of capital transfer abroad with key characteristic of unproductivity that expressed as excess of losses and expenses caused by investment resources transfer abroad under possible and real economic benefits.

The importance of research of unproductive capital outflow in comparison with other ways of capital export (namely illicit financial flows) is empirically proved due to the statistical data synthesis, according to which the ratio of the capital outflow to GDP, average during the last 5 years, in Ukraine is more than $9 \%$, in China - $2 \%$, in India $-1.5 \%$, in Poland $-8.9 \%$, in the Russian Federation $-2.57 \%$, in Hungary $-13.7 \%$, in Romania $-4.34 \%$. It is proved the significance of capital outflow for such European countries as Hungary, Poland, Romania, and for Mexico where volumes of export of financial capital per capita reached levels of 550-2200 USD per 1 person. Due to this data, new regularity of capital export is empirically discovered and is explained by the impact of geographical location factor with highly developed transborder communications and influence of illegal aspects. But more in-depth examine of this problem is to be provided in future researches.

According to provided analysis of dynamics of unproductive capital outflow, it is confirmed the hypothesis of direct positive dependency of capital outflow from level of economic activity, expressed by indicators of GDP volume and gross value added growth. Such dependence caused by inefficiency of institutional support of strategic investments in economy of Ukraine and results of this situation can be described by the following formula: the more profit in national economy is gained, the more risk of unproductive outflow and the more resources are available for withdrawal abroad.

The regulatory framework proposed in the research is aimed on stimulation of strategic investments, on the improving of the level of investments protection, on the increase of the proposal for investments, on the fostering of the capital turnover in economic system. It is stated that the most powerful regulative impact on investment system in aspect of capital outflow reduction can be yield with help of economic and tax mechanisms. Results of provided researches dedicated to potential effect estimation of the implementation of proposed means of capital outflow reduction demonstrate possible growth of gross value on $20.4 \%$ of present value of this indicator as of 2019 year in a sample of economy of Ukraine.

\section{Acknowledgements}

This publication was prepared within the framework of the scientific project "Development of the Ukrainian investment system on the basis of capital outflow reduction" (КПКВК 6541030).

\section{The contribution of the authors}

Oleksandr Laiko - 50\% (methodology, literature review, research, etc.).

Borys Burkynskyi - 50\% (concept and objectives, literature review, research, etc.).

\section{References:}

Burkynskyi, B. V., Laiko, O. I., \& Talpa, V. P. (2018). Tax instruments of investment development stimulation: international experience and national realities. Economic innovations, 20(1), 32-43. doi: 10.31520/ ei.2018.20.1(66).32-43

Dhar, A. (2021). Identification of Extreme Capital Flows in Emerging Markets. International Review of Economics \& Finance, 71, 359-384. doi: 10.1016/j.iref.2020.09.002

Global Financial Integrity (2020). Financial capital outflow monitoring. Retrieved October 28, 2020 from http://www.gfintegrity.org/issues/data-by-country/

Heiets, V. M. (2006, November 17-24). Spetsialni ekonomichni zony: "chorni diry" chy tochky ekonomichnoho zrostannia? [Special economic zones: "black holes" or points of economic growth?]. Dzerkalo Tyzhnia. Available at: https://zn.ua/ukr/macrolevel/spetsialni_ekonomichni_zoni_chorni_diri_chi_tochki_ekonomichnogo_ zrostannya.html

Heiets, V. M. (2016). Ukraine's economy: key issues and prospects. Economics and Forecasting, 1, 7-22. doi: $10.15407 /$ eip2016.01.007

Holz, C. A. (2020). Understanding PRC investment statistics China Economic Review. Volume 61, June 2020. doi: $10.1016 /$ j.chieco.2020.101461

Ilyina, A. (2017). Investment climate evaluation as an effective detection method for negative impacts on country`s development. Baltic Journal of Economic Studies, 3(5), 162-169. doi: 10.30525/2256-0742/2017-3-5-162-169

Kazuo Ueda (1990). Japanese capital outflows. Journal of Banking \& Finance Japanese capital outflows, 14(5), 1079-1101. doi: 10.1016/0378-4266(90)90027-Y 
Laiko, O. I. (2014). Transformation processes in the investment system of the economy of Ukraine. Odessa: IMPEER of the NAS of Ukraine.

Lunina, I., Bilousova, O., \& Frolova, N., (2020). Tax reforms for the development of fiscal space. Baltic Journal of Economic Studies, 6(3), 48-58. doi: 10.30525/2256-0742/2020-6-3-48-58

Paskhaver, O. Y., \& Verkhovodova, L. T., \& Aheieva, K. M. (2007). Velykyj ukrajinskyj kapital: vzajemovidnosyny $z$ vladoju i suspilstvom [Great Ukrainian capital: the relationship with power and society]. Kyiv: Dux i Litera.

Scott Davis, J. \& Van Wincoop, E. (2018). Globalization and the Increasing Correlation between Capital Infows and Outfows. Journal of Monetary Economics, 100 (December 2018), 83-100. doi: 10.1016/j.jmoneco.2018.07.009 The National Bank of Ukraine (2020). The balance of payments. Retrieved October 28, 2020 from https://bank.gov.ua/en/statistic/sector-external/data-sector-external

The National Bank of Ukraine (2019). Inflation Report 2019. Retrieved October 28, 2020 from https://bank.gov.ua/ en/monetary/report

The National Bank of Ukraine (2020). Official Exchange Rates 2020. Retrieved October 28, 2020 from https: / / bank.gov.ua/en/markets/exchangerates?date $=2020-12-03 \&$ period $=$ daily

The State Statistics Service of Ukraine (2019). Capital investment sources 2010-2019. Retrieved October 28, 2020 from http://www.ukrstat.gov.ua/operativ/operativ2007/ibd/iokjf/iokjf_e10-13_bez.htm

The State Statistics Service of Ukraine (2020). Index of capital investment by type of economic activity for 2020 (to corresponding period of previous year). Retrieved October 28, 2020 from http: //www.ukrstat.gov.ua/operativ/ operativ2020/ibd/iki_ed/ikedvp_2020.xlsx

UNCTAD (2019). Global investment trends in 2019 and beyond. Retrieved October 28, 2020 from https://unctad.org/press-material/global-investment-trends-2019-and-beyond

Vartsaba, V., \& Leshuk, H. (2017). Evaluation of investment attractiveness indicators of regions in Ukraine. Baltic Journal of Economic Studies, 3(5), 38-44. doi: 10.30525/2256-0742/2017-3-5-38-44

World Bank (2020). GDP growth (annual \%) - Ukraine. Retrieved October 28, 2020 from https: / / data.worldbank.org/indicator/NY.GDP.MKTP.KD.ZG?locations=UA

World Investment Forum (2018). Official statements 2018. Retrieved October 28, 2020 from https://worldinvestmentforum.unctad.org/2018-official-statements 